"The Second World War, like the First, expedited the use of many unfamiliar woods. . . "Up to the time of his death in 1946, Mr. Alexander Howard, with unfailing enthusiasm, examined these timbers and recorded their characteristics, particularly with a view to their use as substitutes for those woods which had become scarce or unobtainable owing to war conditions.

"The results of this study, and of research in many other directions, are to be found here in the third and greatly enlarged edition of this standard work, while all the matter which appeared in the previous editions has been revised and brought up to date."

\title{
ANNUAL MEETING OF SOCIETY
}

The 1949 annual meeting of the Canadian Society of Forest Engineers will be held in Toronto, October 24 to 26. Murray Morison, Department of Lands and Forests, Toronto, is chairman of the Annual Meeting Committee.

A detailed report descriptive of this meeting will appear in the September issue.

\section{CANADIAN INSTITUTE OF SURVEYING AND PHOTOGR AMMETRY}

The Canadian Institute of Surveying, which has done excellent work in furthering the interests of the surveying profession in Canada, has now, by a vote of its membership, become the Canadian Institute of Surveying and Photogrammetry. This change is of considerable interest to foresters, particularly those who are interested in aerial photography.

In view of this change it is expected that foresters generally will take more interest in the work of the Institute. Incidentally, the new President, H. E. Seely, Chief of the Air Surveys Division of the Dominion Forest Service, is the first forester ever to hold this office. At the time of writing it was expected that Mr. Seely would attend the forthcoming American Congress of Surveying and Mapping, as the official delegate of the Institute.

Photogrammetry plays a big part in the development of Canada's natural resources, especially forestry.

A degree in forestry is now given favourable consideration by the membership committee. Thus any forester who is interested in joining in the work of the Institute, and in receiving the information which it distributes, would have an excellent basis for obtaining a membership.

The annual fees are $\$ 3.00$ for members and $\$ 2.00$ for junior members. Application may be made to W. L. MacIlquham, Secretary-Treasurer, 41 Grove Ave., Ottawa, Ont.

\section{SCHLICH MEMORIAL AWARD}

The winner of the 1948-49 Schlich Memorial Award is James D. Clark who graduated in May, 1949, from the University of British Columbia with the degree of B.S.F.

James Clark was born in Nanaimo, B.C., November 21, 1924. He attended primary and high school in Nanaimo at St. Ann's Academy. He 
was at the University of British Columbia from 1944 to 1949 and was chairman of the Forestry Club Educational Committee during the 1948-49 session. During the summer months he was with the B.C. Forest Products for five summers at their sawmill at Youbou, Vancouver Island, and for one summer on a railroad survey at their San Juan Logging Division, Port Renfrew, V.I. In the summer of 1948 he was employed on a survey for the Canadian Forest Products at their Nimpkish Valley operation, Vancouver Island.

After graduation he will work for the Alberta Forest Service at Edmonton, Alberta. 